\title{
Riconnettere presente e passato: la ricostruzione virtuale delle cucine del monastero dei Benedettini a Catania
}

\author{
Nicoletta Campofiorito \\ Cettina Santagati
}

Abstract

Il contributo illustra la sperimentazione condotta sulle cucine del Monastero dei Benedettini a Catania (oggi Museo della Fabbrica dell'Ateneo catanese) finalizzata alla ricostruzione virtuale delle diverse trasformazioni subite nel tempo e non più visibili se non attraverso il medium di una ricostruzione virtuale.

Obiettivo dello studio è la riconnessione tra presente e passato attraverso l'atto critico di osservazione, l'indagine storica, il rilievo e la modellazione 3D. Le tracce del passato sono state cercate e ritrovate attraverso uno studio analitico delle fonti (raccolte iconografiche, bibliografiche, cartografie storiche, documenti di archivio) ed un rilievo dello stato di fatto che messi a confronto hanno guidato la formulazione delle ipotesi in una sintesi tra geometria, forma, architettura e tecniche costruttive. La metodologia messa a punto ha fatto propri i principi della Carta di Londra e di Siviglia in merito alle ricostruzioni 3D con particolare riferimento alla 'trasparenza scientifica' e al 'rigore storico' per una ricostruzione della memoria dei luoghi, il cui racconto illustrasse le scelte e le ipotesi a partire dalle fonti (paradati).

Parole chiave

ricostruzione virtuale, Regio Osservatorio Astrofisico, modellazione 3D, paradata, trasparenza scientifica.

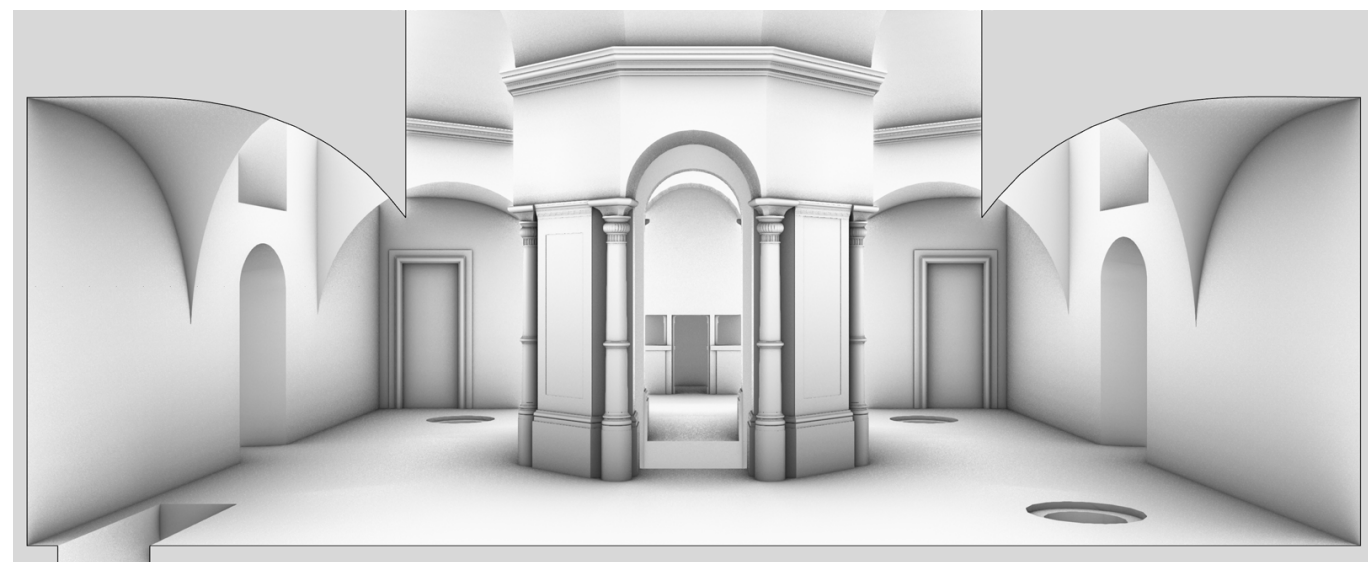


"Ricostruire significa collaborare con il tempo, nel suo aspetto di 'passato', coglierne lo spirito o modificarlo, protenderlo quasi verso un più lungo avvenire; significa scoprire sotto le pietre il segreto delle sorgenti"

[Yourcenar 2005, p. I2I].

\section{Introduzione}

II Monastero dei Benedettini a Catania è un sito complesso, ricco di stratificazioni (dal periodo greco-romano ad oggi) e luogo della memoria degli interventi legati al progetto di riqualificazione di Giancarlo De Carlo, che ha portato la fabbrica dallo stato di degrado in cui versava all'attuale utilizzo come sede del Dipartimento di Scienze Umanistiche dell'Università di Catania. Alcuni interventi hanno cancellato in maniera irreversibile alcune fasi le cui tracce oggi possono essere ritrovate solo attraverso la documentazione storica (fotografie, disegni, relazioni tecniche, documenti d'epoca) e qualche segno appena percepibile.

In questi casi, il disegno digitale, e nello specifico la modellazione 3D, diviene il mezzo attraverso cui indagare e riannodare il legame spezzato tra presente e passato e ricostruire la memoria delle diverse fasi storiche.

Attraverso una lettura critica delle fonti (raccolte iconografiche, bibliografiche, cartografie storiche, documenti di archivio) e il rilievo è possibile formulare delle ipotesi in una sintesi tra geometria, forma, architettura e tecniche costruttive, ricostruendo e visualizzando virtualmente alcuni tasselli mancanti al racconto della fabbrica.

Lo studio è finalizzato alla ricostruzione delle trasformazioni non più visibili subite nel tempo dai locali delle cucine dei Benedettini, oggi sede del museo della Fabbrica. II modello 3D ha costituito il fulcro del processo, il luogo della sperimentazione e della sintesi in cui formulare e verificare le ipotesi. Nel contempo, la ricostruzione virtuale ha avuto come riferimento costante la Carta di Londra e i principi di Siviglia, in particolare i concetti di 'trasparenza scientifica' e 'rigore storico', in modo tale da rendere intellegibile il processo e le fonti utilizzate a supporto delle ipotesi formulate.

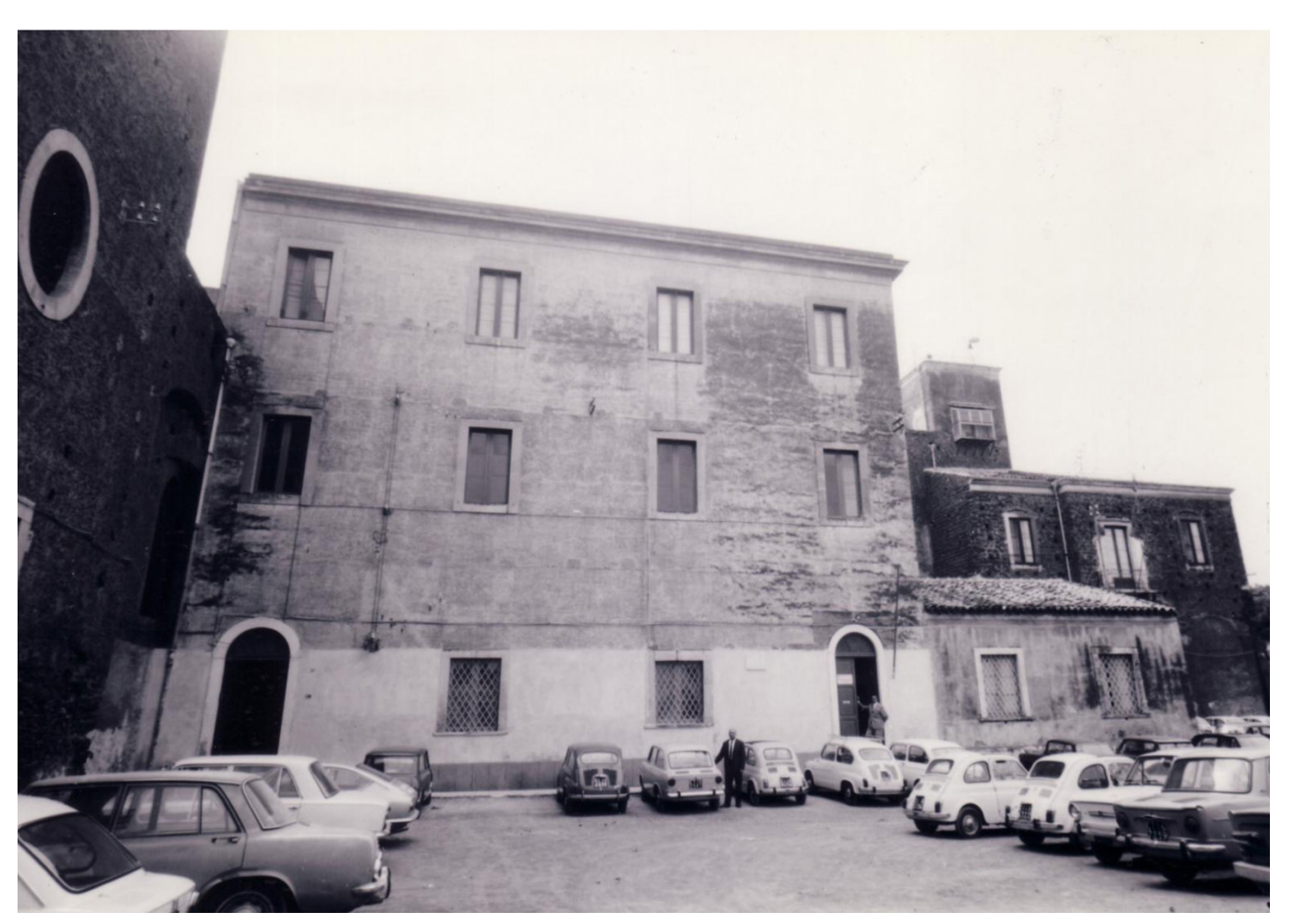




\section{Stato dell'arte}

Le ricostruzioni virtuali rappresentano un elemento di strategica importanza per progetti di divulgazione, soprattutto in campo didattico-museale. Sono diventate parte integrante di mostre e allestimenti grazie alla loro natura versatile e alla loro capacità di raccontare realtà complesse in maniera semplice e immediata, facilitandone la comprensione. Raramente tali ricostruzioni vengono accompagnate dai paradati, che raccontano il processo che ha portato al risultato finale. In ambito internazionale già dal 2009 con la Carta di Londra e nel 2012 con i principi della Carta di Siviglia si è tentato di individuare alcuni elementi chiave per le ricostruzioni virtuali [Bentkowska-Kafel et al. 20 I2; Brusaporci et al. 20 I3, pp. 55-68].

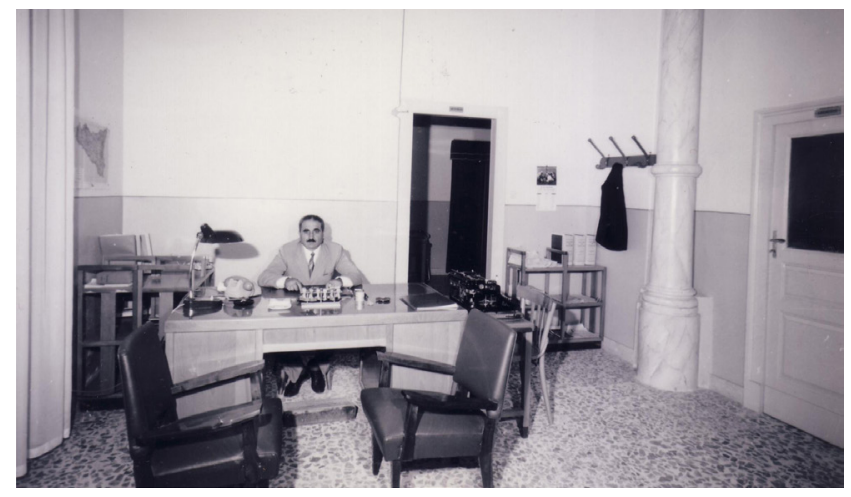

Nella ricostruzione dei quartieri Alessandrino e della Suburra di Roma [Cianci et al. 20 I6; Cianci 2016, pp. 80-90], sono stati definiti tre livelli di autenticità del modello: completa (ricostruzione da prospetti d'archivio e fotografie storiche); parziale (da planimetrie d'archivio e prospetti attuali); tipologica (ricostruzione da catastali confrontati con l'abaco delle tipologie).

Una soluzione diversa è stata proposta nell'ambito delle ricostruzioni virtuali del Foro Romano cui è stata affiancata una piattaforma WIKI contenente le fonti e il processo ricostruttivo per ogni singolo modello 3D [Bartz et al. 2016].

Un ulteriore metodo adottato è il "Metodo Ricostruzione-Argomentazione" [Pfarr-Harfst et al. 2016] in cui gli screenshots o i renders del modello 3D vengono affiancati da una tabella delle fonti e un testo esplicativo, individuando una triade "Ricostruzione- Argomentazione-Fonte" a cui viene associato un valore qualitativo di attendibilità.

Un'altra possibilità è I'"Extended Matrix" [Demetrescu 20I5, pp.42-55], un linguaggio formale che si basa su un approccio stratigrafico in grado di collegare la documentazione archeologica e la ricostruzione virtuale, tenendo traccia di tutto il processo di ricostruzione, indicando la fonte utilizzata e come questa è stata interpretata.

\section{Le cucine del Monastero dei Benedettini a Catania}

Il Monastero di San Nicolò l'Arena rappresenta uno dei luoghi chiave della città di Catania. La costruzione, iniziata a partire dal 1558 sulla Collina di Montevergine, venne interessata prima dalla colata del 1669 e successivamente dal terremoto del I693. A partire dal I 866 il complesso monastico ha subito numerose trasformazioni per adattare la fabbrica a diversi usi civili.

Gli spazi delle cucine e degli scantinati, questi ultimi denominati il 'ventre', sono stati progettati dall'architetto Giovan Battista Vaccarini a partire dal 1739, direttamente sulla colata lavica del I669, e poi adibiti a sede del Regio Osservatorio Astrofisico tra la fine dell'Ottocento e la prima metà del Novecento. 
A partire dagli anni '70 del secolo scorso l'Università degli Studi di Catania ha acquisito il monastero dando il via a un lungo e laborioso processo di recupero che ha portato all'utilizzo dell'edificio come sede del Dipartimento di Scienze Umanistiche e alla istituzione del Museo della Fabbrica.

\section{Metodologia}

La metodologia messa a punto ha previsto una prima fase di raccolta del materiale con indagini storico-bibliografiche, ricerca della documentazione storica (immagini, cartografie, disegni), ricerca di archivio (Museo della Fabbrica, Archivio di Stato); una seconda fase di rilievo dello stato di fatto (condotto mediante tecniche dirette integrate con fotogrammetria); una successiva sintesi finalizzata all'individuazione delle trasformazioni più significative e all'elaborazione di un sistema per l'esplicitazione dei paradati relativi alla ricostruzione e ai livelli di attendibilità della stessa; la modellazione 3D e la resa del modello.

\section{La ricerca storica e d'archivio}

Presso l'Archivio del Museo della Fabbrica sono stati reperiti e consultati documenti, fotografie storiche, articoli ed elaborati inerenti tanto il progetto di recupero quanto gli eventi storici del monastero.

Presso l'Archivio di Stato di Catania sono stati ritrovati i documenti originali relativi alla costruzione della scala d'accesso alla specola e dell'alloggio del personale del Regio Osservatorio di Catania (fig. 3) [lozzia 2009-20 I 0].Tali documenti forniscono informazioni sui livelli demoliti e recano traccia delle cucine nella configurazione originaria. Tra questi, le tre cupolette di ventilazione nel vano principale della cucina che vengono testimoniate anche dagli schizzi di Léon Dufourny del 1789 (fig. 4).

Fig. 3. Progetto per la costruzione della scala e degli alloggi del personale per il Regio Osservatolon Astico, sezior longitudinale passante per

Fig. 4. Léon Dufourny, Pianta e sezione della cucina, 1789.
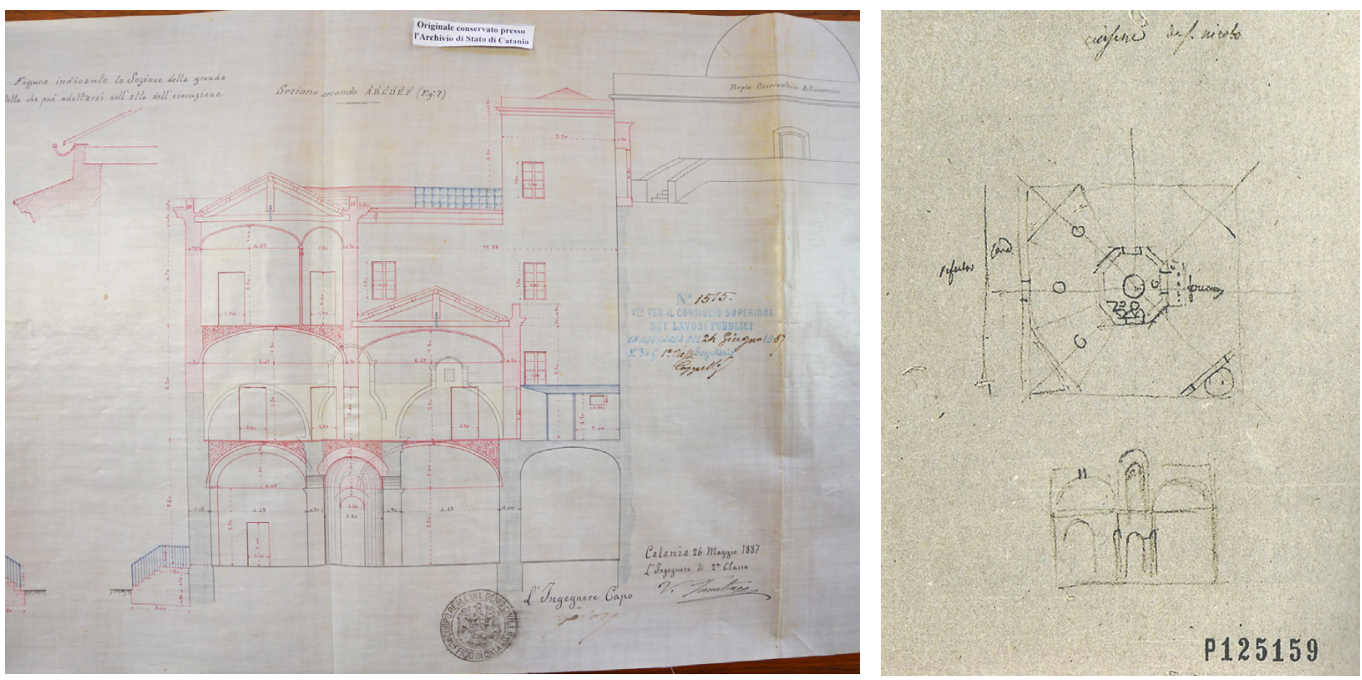

\section{Rilievo}

II rilievo dei luoghi è stato condotto mediante metodo diretto, verificando e integrando gli elaborati dell'ufficio tecnico dell'Università. Laddove necessario, sono stati realizzati dei dataset fotografici elaborati con Metashape (Agisoft) (fig. 5) al fine di realizzare modelli poligonali texturizzati da cui ricavare le misure necessarie in ambiente Rhinoceros. 


\section{La ricostruzione virtuale}

Sono state individuate tre principali fasi nelle trasformazioni subite dalle cucine andando a ritroso nel tempo dalla configurazione attuale, alla fase del Regio Osservatorio Astrofisico (I887 - metà XX), fino ad arrivare alla fase dei monaci benedettini (I669-| 867).

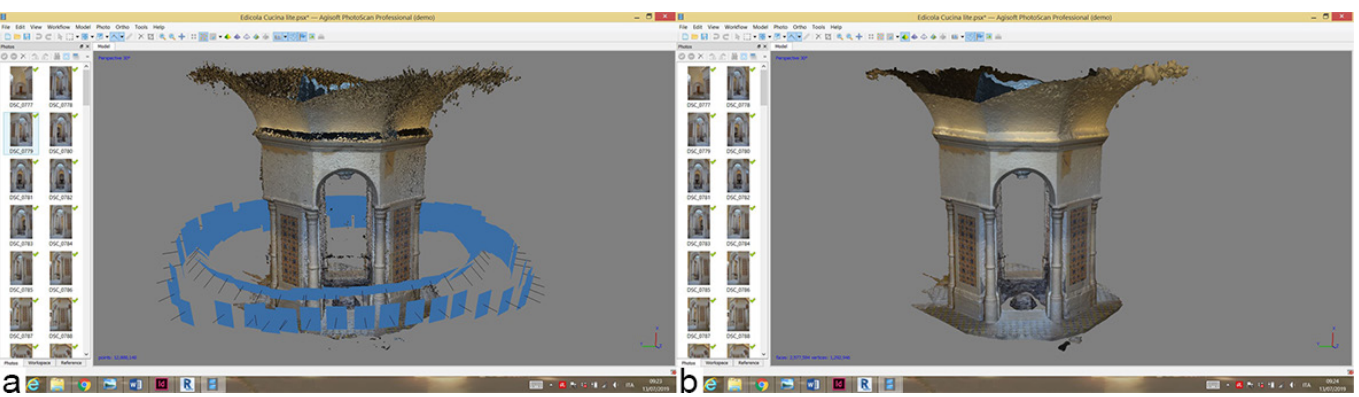

\section{Stato di fatto $(X X I$ sec. - metà $X X$ sec.)}

Gli ambienti delle cucine (fig. 6b) hanno un impianto planimetrico rettangolare e sono accessibili internamente dal Refettorio (aula magna) attraverso un ambiente passavivande che funge da filtro e dall'esterno (Piazza Vaccarini) attraverso un androne di collegamento. L'androne è chiuso da un vano scala (realizzato durante i lavori del Regio Osservatorio) che consente di accedere ai livelli superiori.

Le cucine sono un ambiente quadrangolare con al centro un'edicola/fornello su base ottagonale con quattro aperture con archi a tutto sesto sorretti da colonne orientate coerentemente lungo gli assi di simmetria del quadrato. Superiormente l'edicola è delimitata da una cornice su cui poggia la copertura dell'ambiente, costituita da una volta a botte anulare a base ottagonale. Il passaggio dalla pianta quadrata a quella ottagonale è realizzato attraverso delle unghie. La volta anulare e la canna fumaria sono una riproduzione di quelle originali, demolite a fine Ottocento.

Lungo le diagonali della stanza sono disposti l'originaria scala di collegamento con lo scantinato e tre fori circolari per il passaggio delle derrate alimentari.

Sul lato ovest le cucine confinano con un fabbricato costruito nel 1927 che oggi accoglie gli ambienti di servizio del Museo della Fabbrica e la nuova scala di collegamento col livello inferiore, affiancata dall'ascensore.

Fig. 6. Ex cucine del Monastero allo stato di fatto: a) pianta del 'ventre'

b) pianta del piano terra.
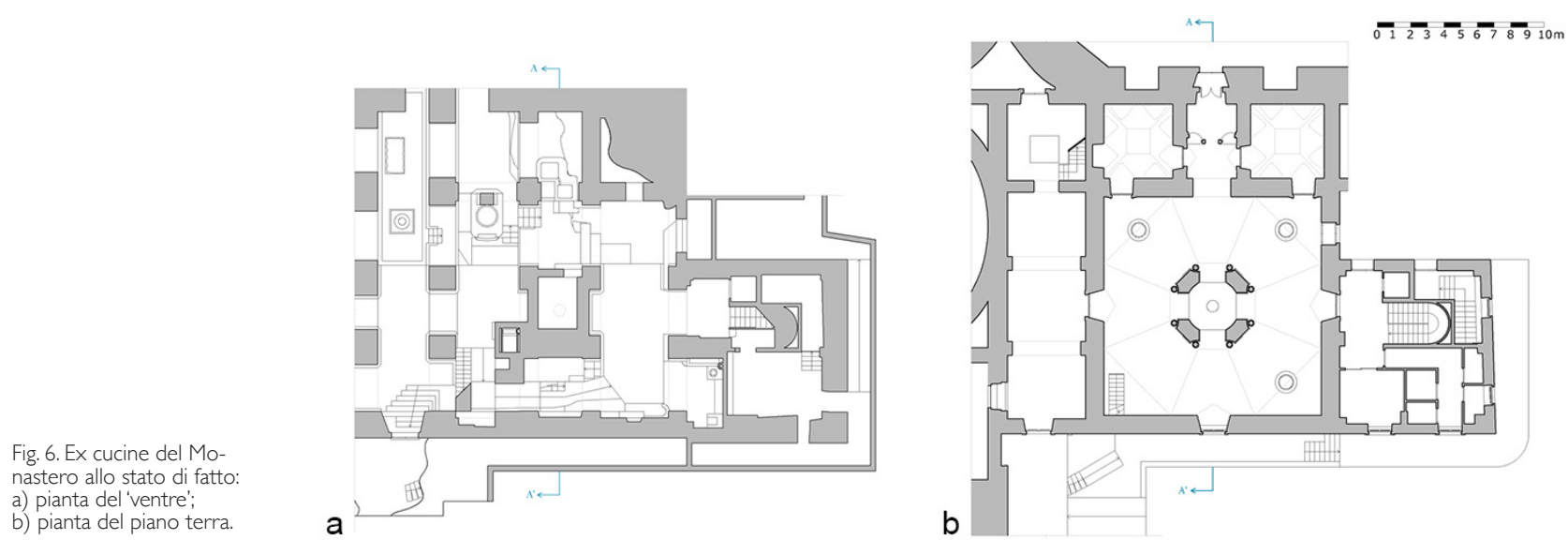
Il livello semipogeo, occupa una vasta area al di sotto delle cucine, del refettorio piccolo, di parte della biblioteca e del corridoio dell'orologio. La parte corrispondente alle cucine viene chiamata 'ventre' (fig. 6a), l'area al di sotto del refettorio piccolo e dell'androne era per lo più occupata dal Laboratorio di Geodinamica di cui si conservano ancora oggi la base dei tronometri, del grande sismometrografo e la massa oscillante di un pendolo.

Gli spazi del 'ventre' sono scanditi da pilastri e archi che poggiano direttamente sul banco lavico e che sostengono volte a crociera.

L'ambiente semipogeo è illuminato a nord da tre finestre che si affacciano sulla piazza e da un ingresso rinvenuto durante i lavori di recupero. Nella volta a crociera in corrispondenza di suddetto ingresso si nota la traccia della scala che un tempo permetteva di scendere dall'androne direttamente al Laboratorio di Geodinamica.

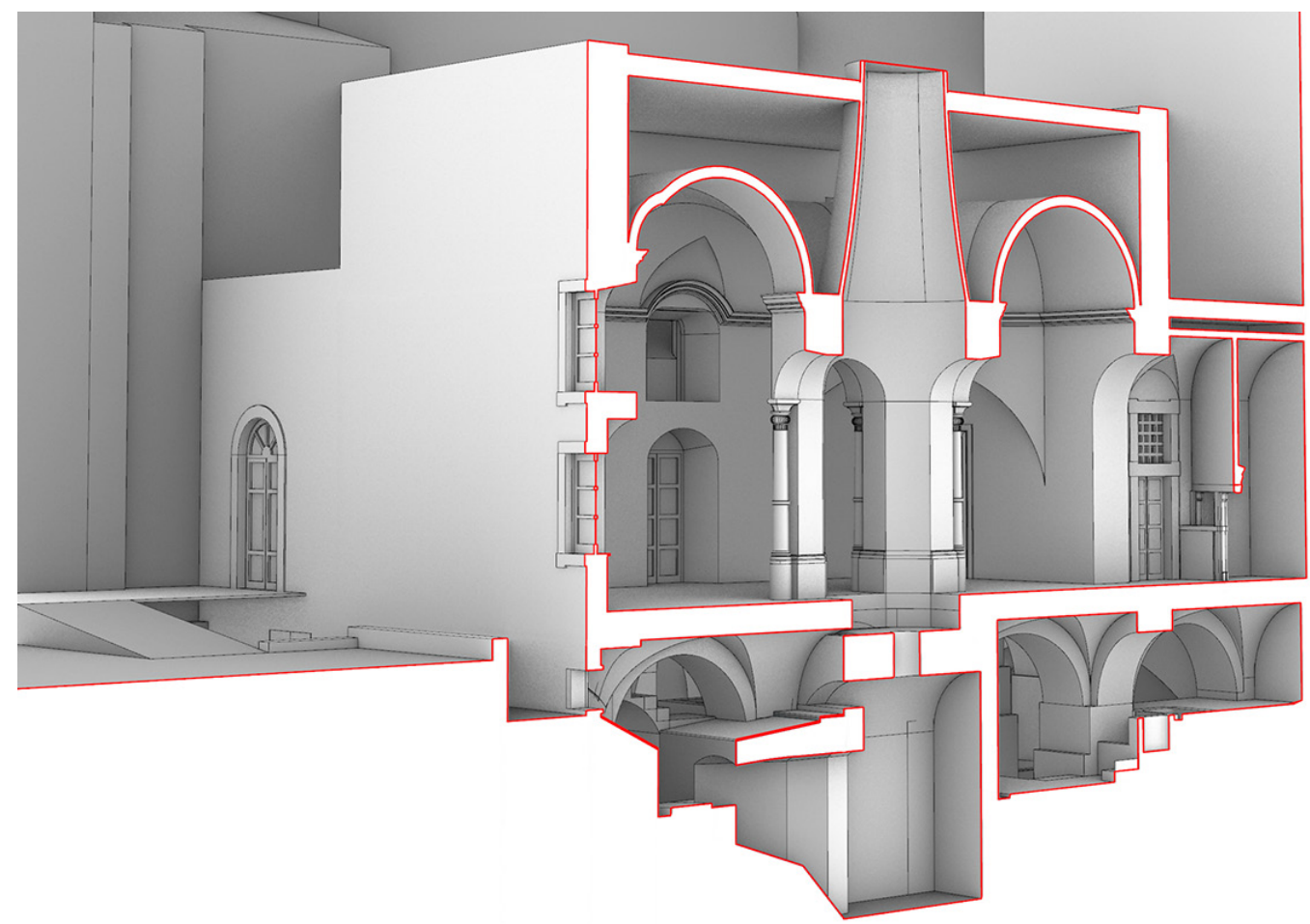

\section{Regio Osservatorio Astrofisico (I887 - metà XX sec.)}

Uno degli interventi più incisivi apportati dall'Osservatorio è stato la realizzazione di due livelli al di sopra delle cucine e dell'androne che ha comportato l'eliminazione della volta originale della cucina con le presunte tre cupolette di ventilazione e la canna fumaria del forno. La ricostruzione in pianta dell'assetto del piano terra (fig. 8b) si è avvalsa del rilievo redatto dall'Ufficio Tecnico negli anni '70, confrontato con le foto storiche delle singole stanze. II progetto del 1887 ha costituito invece il supporto per ricostruire i livelli superiori (figg. 8c, d, e). Solo una parte dell'ambiente semipogeo (fig. 8a) venne utilizzata e adibita a Laboratorio di Geodinamica (area al di sotto dell'androne e del refettorio piccolo) e la sua parziale ricostruzione ha tenuto in considerazione le tracce in situ, le foto d'epoca e una pianta abbozzata dei locali. 


\section{Monaci Benedettini (1669-1867)}

L'intervento di recupero condotto sugli ambienti delle cucine ha riportato alla configurazione originaria alcuni elementi dell'edificio, tra cui il vano principale con la volta anulare a pianta ottagonale, il forno progettato da Vaccarini e le finestre sovraluce.

Per la ricostruzione virtuale delle parti rimaste alterate o che sono state modificate durante i suddetti lavori si è fatto riferimento agli schizzi di Léon Dufourny del 1789 (fig. 4), al verbale di cessione del monastero redatto dall'ingegnere Carlo Bettoli il 4 gennaio I 868 su incarico della Direzione del Demanio e delle Tasse, al rilievo di Vaccari del I88I e al progetto del Regio Osservatorio Astrofisico del I 887 (fig. 3).

Dagli schizzi di Dufourny e dal verbale dell'ing. Bettoli [Rizzo Pavone et al. 2000, p. 56] è stata ipotizzata la presenza di alcuni fornelli in prossimità dell'Edicola e di quattro muri nel vano centrale della cucina, a chiusura dei quattro angoli. Dufourny aveva rappresentato inoltre tre cupolette poste al di sopra della volta anulare della cucina.

La conferma di questi elementi, insieme ad altre utili informazioni sui prospetti Nord e Ovest, ci sono giunti dal progetto del Regio Osservatorio Astrofisico (I 887).
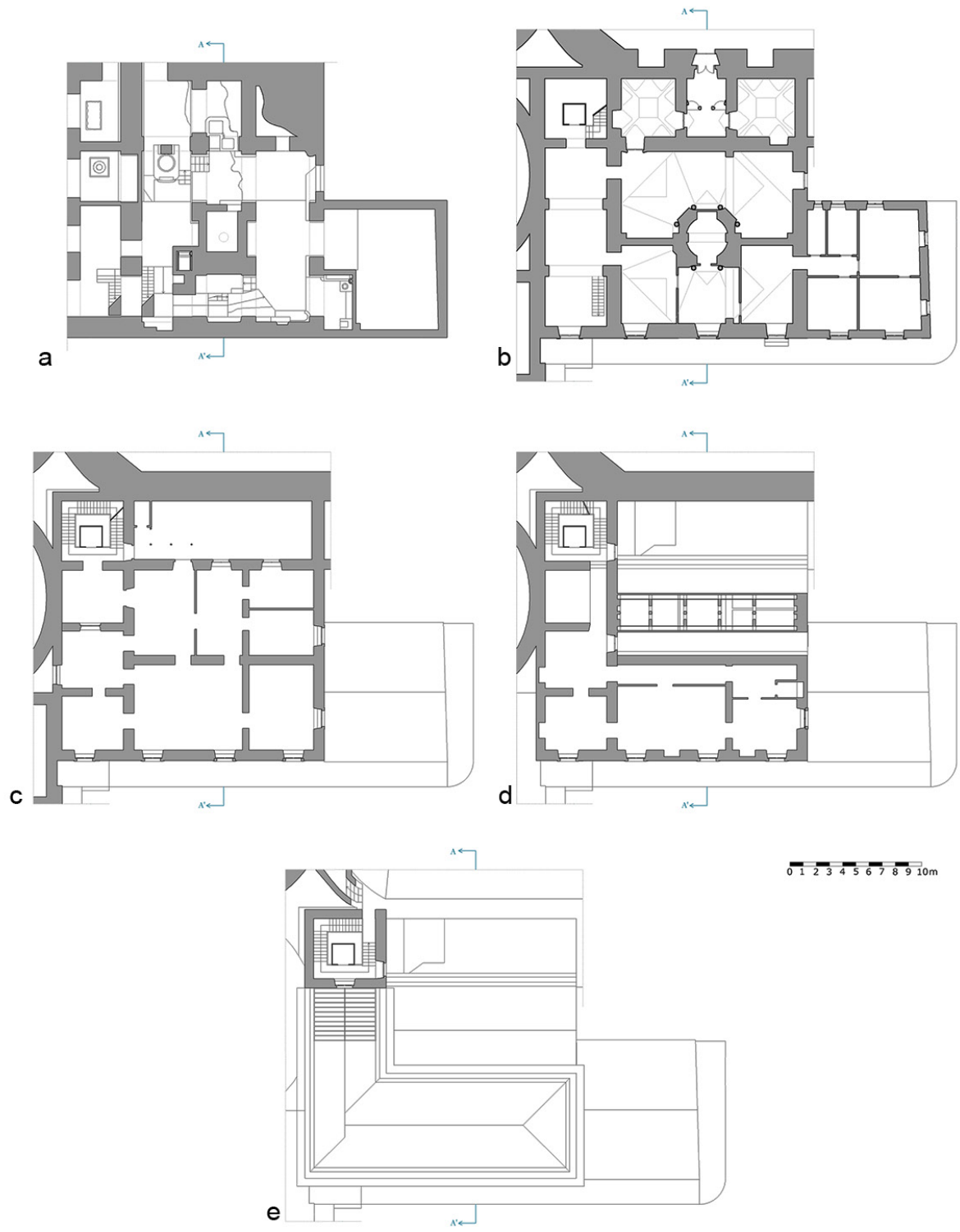
Per le coperture, il verbale di cessione riporta la presenza di una volta in canne e gesso con copertura a falde sovrastante nel vano laterale a ovest [Rizzo Pavone et al. 2000, p. 56], invece, per il vano centrale e per l'androne non è stata ritrovata alcuna documentazione. Nel vano centrale è stata quindi supposta una copertura a falde, al di sopra della volta anulare; si è invece ipotizzato che l'androne fosse uno spazio aperto (per la presenza di porte e finestre sopraluce).

Del 'ventre' non è stato reperito nessun elaborato, per cui si può solo supporre che la parte ad ovest comprendesse originariamente solo la stanza con i due forni.

Dai lavori di recupero è emersa la presenza di un antico ingresso da Piazza Vaccarini, ostruito durante gli anni del Laboratorio di Geodinamica e ripristinato dall'Università.

Non sono state ritrovate tracce visibili di una scala a servizio di questa apertura, tuttavia ne è stata supposta la presenza ai tempi dei monaci.

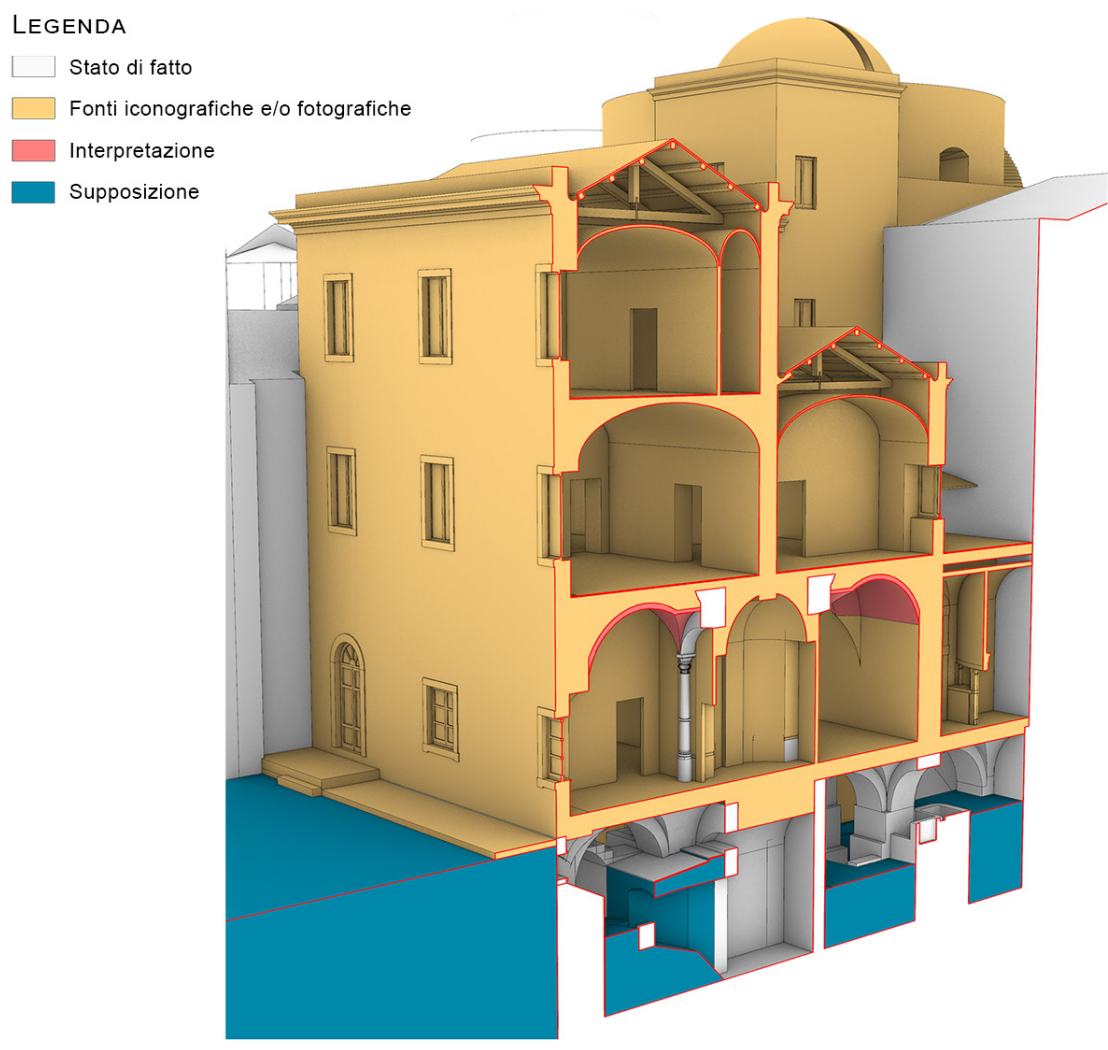

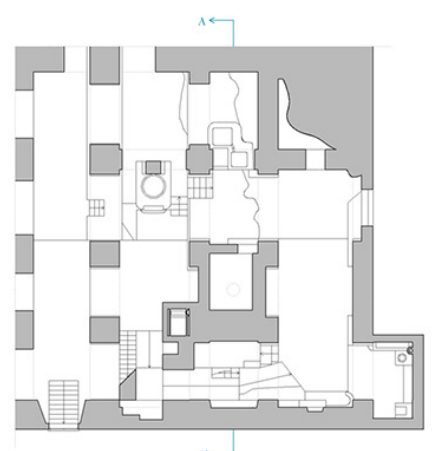

a N

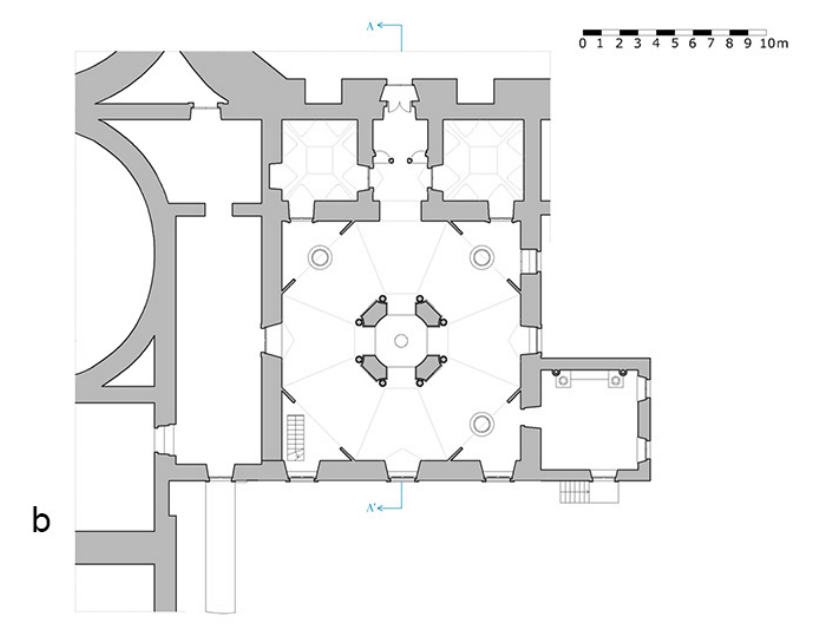


Infine, l'interpretazione del rilievo del $188 \mid$ di Vaccaro e la presenza di quella che sembra essere una finestra, portano a pensare che anche il fronte ovest in passato non fosse completamente al di sotto della quota esterna.

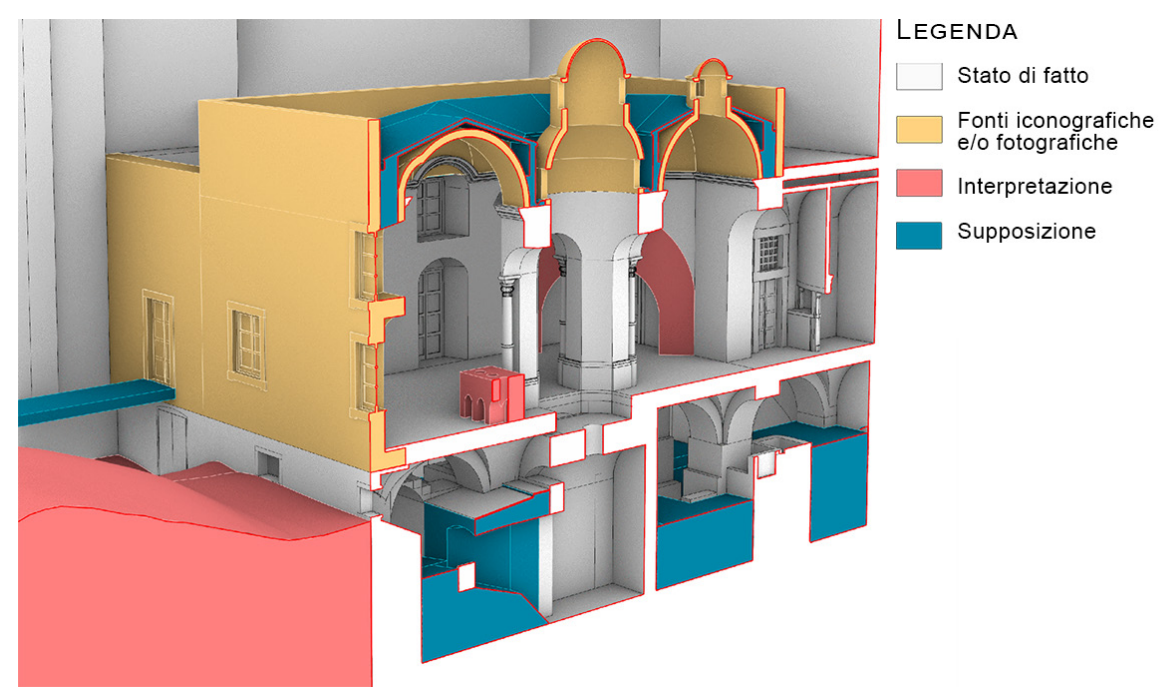

\section{Visualizzazione dei paradati}

Al fine di archiviare i paradati e visualizzarli contestualmente alla ricostruzione, si è proceduto mediante due approcci:

- il primo metodo illustra visivamente il grado di attendibilità di ogni parte del modello tramite una scala colori. Sono state definite quattro categorie (stato di fatto, da fonti iconografiche e/o foto storiche, interpretazione, supposizione) e ad ognuna di esse è stato associato un diverso colore riportato in tabella.

- il secondo metodo associa in ambiente Rhinoceros alle singole componenti del modello in maniera dettagliata tutte le informazioni che le riguardano (fig. I 2). La ricostruzione virtuale è pertanto interrogabile, le informazioni sono visualizzabili nella finestra delle proprietà, alla scheda 'testo utente attributi'. Le schede degli attributi, inoltre, possono essere sia importate che esportate in formato .cvs e .txt.

\section{Conclusioni e sviluppi futuri}

Riannodare presente e passato attraverso la rappresentazione digitale, questo l'obiettivo del progetto di ricerca. In una società profondamente influenzata dalla comunicazione visiva, le ricostruzioni virtuali affascinano i nostri sensi ma allo stesso tempo possono divenire un mezzo per una conoscenza approfondita del manufatto e per la narrazione della sua complessità. È quindi fondamentale associare ad esse i paradati che consentono di risalire al processo ricostruttivo. I modelli 3D realizzati per il Monastero dei Benedettini hanno di fatto facilitato il confronto tra le diverse epoche e configurazioni spaziali e potranno essere utilizzati in svariati modi, attingendo ad altri campi come quello cinematografico o videoludico, al fine di raggiungere una maggiore interazione tra utente e bene culturale.

\section{Crediti}

Cettina Santagati ha scritto i paragrafi: Introduzione, Stato dell'arte, Metodologia, Conclusioni e sviluppi futuri.

Nicoletta Campofiorito ha scritto i paragrafi: Le cucine del Monastero dei Benedettini a Catania, La ricerca storica e d'archivio, II Rilievo, La ricostruzione virtuale. 
Fig. 12. Screenshot dimostrativo per la procedura proposta di archiviazione e visualizzazione dei paradati su Rhinoceros 6 .

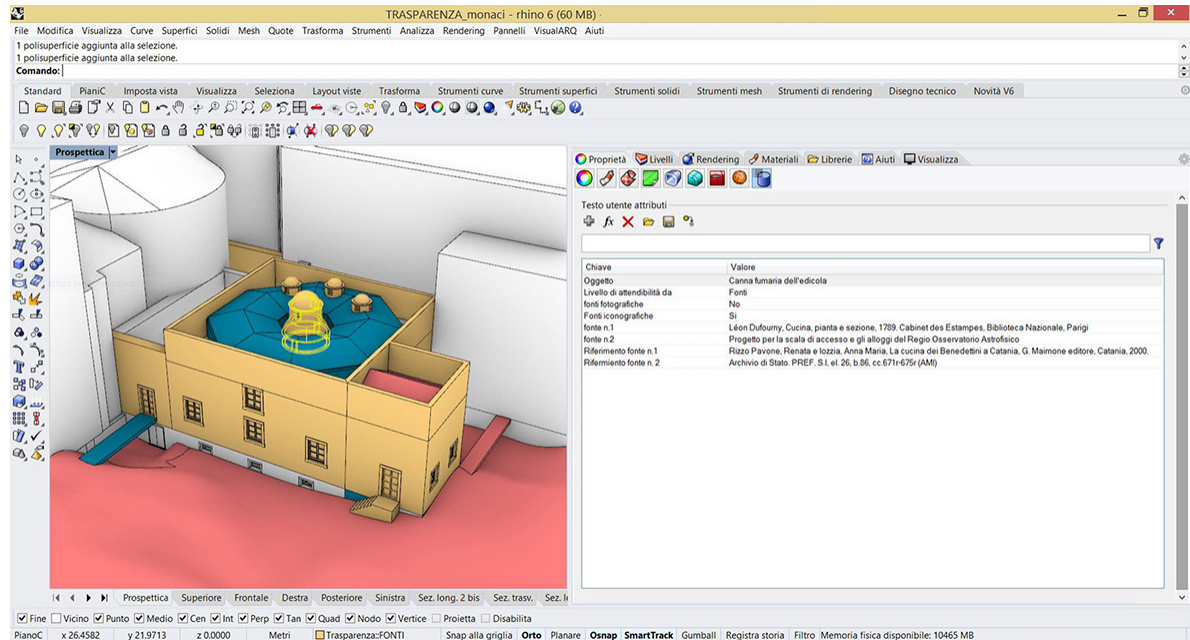

\section{Riferimenti bibliografici}

Bartz Jessica, Holter Erika, Muth Susanne (2016). Digitales Forum Romanum. Chancen und Grenzen virtueller Rekonstruktion und Simulation. In Zimmer Kathrin Barbara. Von der Reproduktion zur Rekonstruktion - Umgang mit Antike(n). II Summerschool vom I6-19 Juni 2014 in Tübingen, vol. 21, pp. 193-208. Rahden/Westf:Verlag Marie Leidorf GmbH.

Bentkowska-Kafel Anna, Denard Hugh, Baker Drew (a cura di) (2012). Paradata and Transparency in Virtual Heritage. Farnham: Ashgate.

Brusaporci Stefano (2017). The Importance of Being Honest: Issues of Transparency in Digital Visualization of Architectural Heritage. In Ippolito Alfonso (ed.). Handbook of Research on Emerging Technologies for Architectural and Archaeological Heritage. Hershey: IGI Global Gl Global, pp. 66-93.

Brusaporci Stefano, Trizio Ilaria (20/3). La Carta di Londra e il Patrimonio Architettonico: riflessioni circa una possibile implementazione. In SCIRES-IT. SCientific RESearch and Information Technology, 3, Issue 2, pp. 55-68.

Cianci Maria Grazia, Calisi Daniele, Geremia Francesca (2016). II quartiere Alessandrino. Una ricostruzione virtuale filologica ed emblematica: alla ricerca dei valori originali dei tessuti urbani demoliti. In AAVV. Atti del Convegno Internazionale on Cultural Heritage. Present Challenges and Future Perspectives. Roma, 2 I-22 novembre 20 I 4. Roma: Croma.

Cianci Maria Grazia (2016). Gestione, ricostruzione e comunicazione di sistemi urbani complessi. II quartiere della Suburra a Roma. In Disegnare Idee Immagini, 52, pp. 80-90.

Demetrescu Emanuel (20I5). Archaeological stratigraphy as a formal language for virtual reconstruction. Theory and practice. In Journal of Archaeological Science, 57, pp. 42-55.

Iozzia Anna Maria (a cura di). (2009-20 I0). Percorsi di storia e traguardi scientifici dell'Osservatorio Astrofisico di Catania. Mostra allestita presso l'Archivio di Stato di Catania dal 16 dicembre 2009 al 27 febbraio 2010.

Pfarr-Harfst Mieke, Grellert Marc (2016). The Reconstruction - Argumentation Method. Proposal for Minimum Standard of Documentation in the Context of Virtual Reconstructions. In loannides Marinos et al. (Eds.). Digital Heritage. Progress in Cultural Heritage: Documentation, Preservation, and Protection. EuroMed 20 16. Lecture Notes in Computer Science. Cham: Springer, vol. 10058, pp. 39-49.

Rizzo Pavone Renata, lozzia Anna Maria (2000). La cucina dei Benedettini a Catania. Catania: G. Maimone editore.

Yourcenar Marguerite (2005). Memorie di Adriano. Seguite dai taccuini di appunti.Torino: EinaudiTraduzione di Storoni Mazzolani, Lidia (Ed. orig. Mémoires d'Hadrien. Paris: Librairie Plon, I95I).

\section{Website}

$<$ http://osiris.itabc.cnr.it/extendedmatrix/>.

$<$ http://www.digitales-forum-romanum.de/>

\section{Autori}

Nicoletta Campofiorito, Università degli Studi di Catania, nicoletta.campofiorito@gmail.com

Cettina Santagati, Università degli Studi di Catania, cettina.santagati@unict.it

Per citare questo capitolo: Campofiorito Nicoletta, Santagati Cettina (2020). Riconnettere presente e passato: la ricostruzione virtuale delle cucine del Monastero dei Benedettini a Catania/Reconnecting present and past: the virtual reconstruction of the kitchens of the Benedictine Monastery in Catania. In Arena A., Arena M., Brandolino R.G., Colistra D., Ginex G., Mediati D., Nucifora S., Raffa P. (a cura di). Connettere. Un disegno per annodare e tessere. Atti del $42^{\circ}$ Convegno Internazionale dei Docenti delle Discipline della Rappresentazione/Connecting. Drawing for weaving relationships. Proceedings of the 42th International Conference of Representation Disciplines Teachers. Milano: FrancoAngeli, pp. $1800-1819$. 


\title{
Reconnecting Present and Past: the Virtual Reconstruction of the Kitchens of the Benedictine Monastery in Catania
}

\author{
Nicoletta Campofiorito \\ Cettina Santagati
}

\section{Abstract}

The experimentation conducted on the kitchens of the Benedictine Monastery in Catania (now the Museo della Fabbrica of the University of Catania) was aimed at the virtual reconstruction of certain features of the monastery that have largely been erased by the numerous transformations it has undergone over the centuries. It was an exercise in reconnecting the present and the past through critical observation, historical investigation, surveying and 3D modelling.

Traces of the past were identified through the analytical study of source material (iconographic collections, bibliographic, historical maps, and archive documents) and architectural surveying, in order to formulate detailed hypotheses covering geometry, shape, architecture and construction techniques. The methodology is based on the London Charter and Seville Principles regarding 3D reconstructions, with particular reference to scientific transparency and historical rigour, in order to clearly indicate the data sources underlying any choice or hypothesis (paradata).

Keywords

virtual reconstuction, Regio Osservatorio Astrofisico, 3D modeling, paradata, scientific transparency.

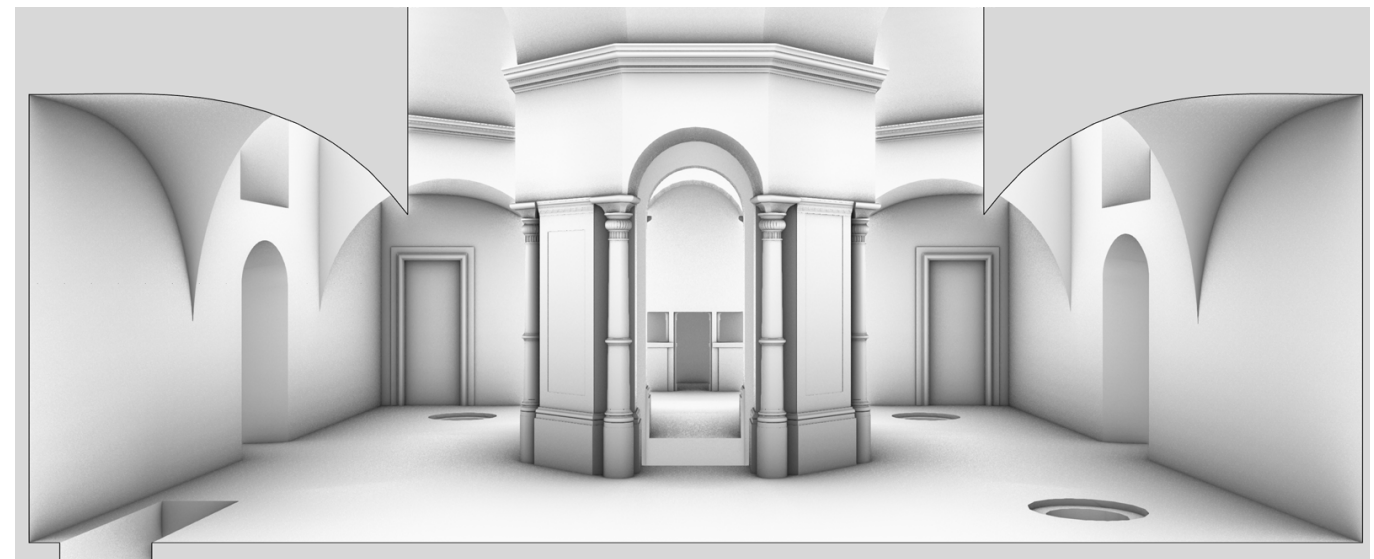


"To reconstruct is to collaborate with time gone by, penetrating or modifying its spirit, and carrying it toward a longer future. Thus beneath the stones we find the secret of the springsi"

[Yourcenar 2005, p. 121].

\section{Introduction}

The Monastery of the Benedictines in Catania is a complex site that is rich in stratifications that range from the Greek-Roman period to the modern era, including the interventions of Giancarlo De Carlo's requalification project to restore the building from a state of decay to its current manifestation as seat of the Catania University Department of Humanities. Some interventions have irreversibly erased certain historical features whose traces can now only be found in historical documentation (photographs, drawings, technical reports and period documents) or in often barely discernable markings.

It is therefore an ideal candidate for using the digital 3D medium to experience the different historical building phases and allow the link between present and past to be resewn.

Critical reading of the source material (iconographic collections, bibliographic, historical maps, archive documents) was combined with architectural survey to derive virtual reconstructions of missing elements of the building's history from hypotheses involving geometry, form, architecture and construction techniques.

The study aimed to reconstruct the now invisible transformations witnessed by the Benedictine Kitchens, which today constitutes the seat of the Museo della Fabbrica. The heart of the process was a 3D model constructed on the hypotheses that were formulated and tested during the experimentation. The virtual reconstruction abided closely with the Charter of London and the Seville Principles, especially regarding scientific transparency and historical rigor, in order to ensure that the processes and the sources underpinning our hypotheses satisfied certain qualitative criteria.

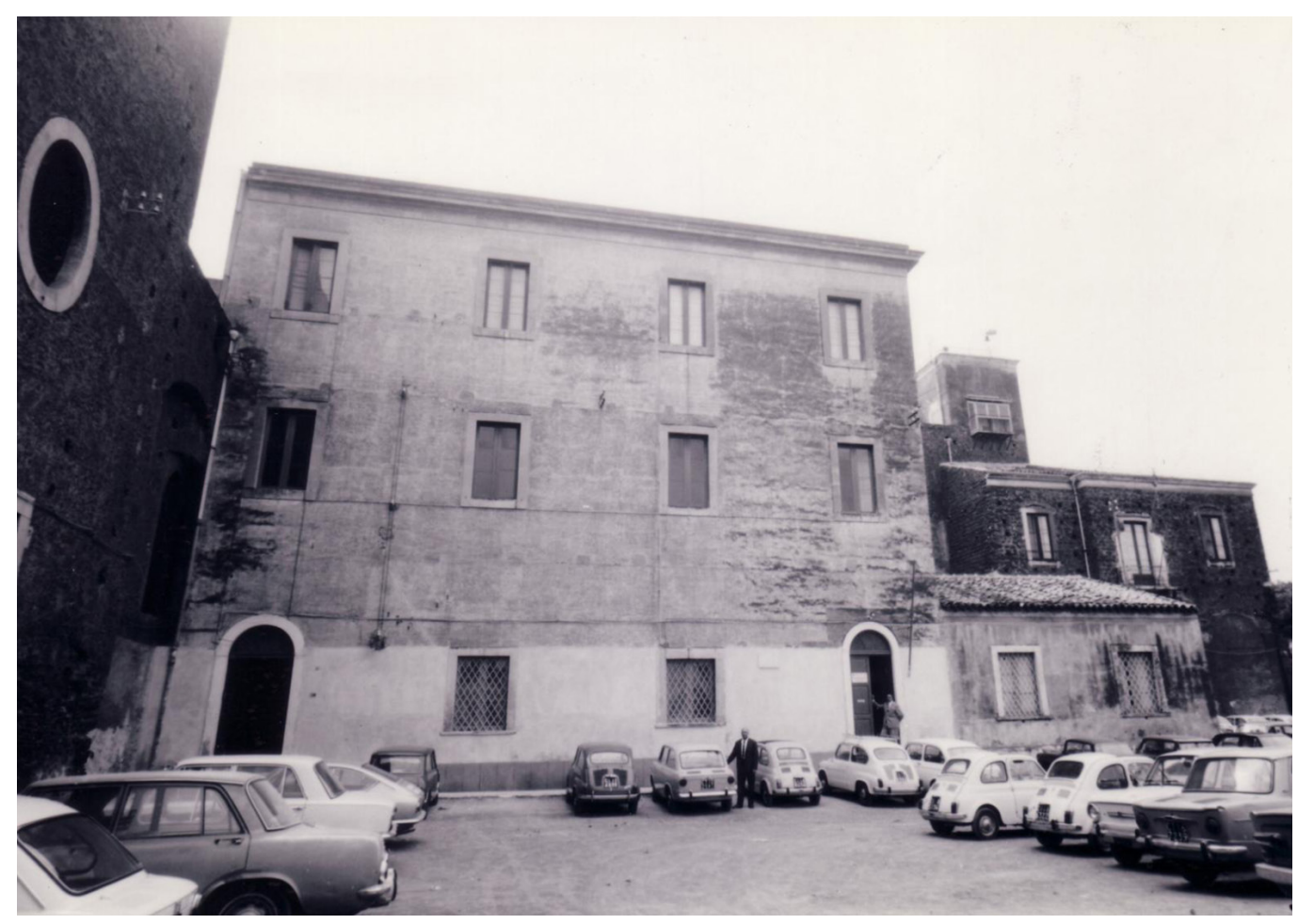




\section{State of the art}

Virtual reconstructions represent an element of strategic importance for dissemination projects, especially in educational contexts and museums, and are now integral to exhibitions and interactive installations thanks to their versatility and ability to render abstract and complex information more palpable and palatable. These reconstructions should, but often do not, contain accompanying paradata that describe the processes from which the results were derived. The 2009 iteration of the London Charter and the 2012 Seville Principles both identify key elements for virtual reconstructions [Bentkowska-Kafel et al. 20 I 2; Brusaporci et al. 2013, pp. 55-68].

Fig. 2. Secretary's office and annexed archives of the Royal Astrophysical Observatory.

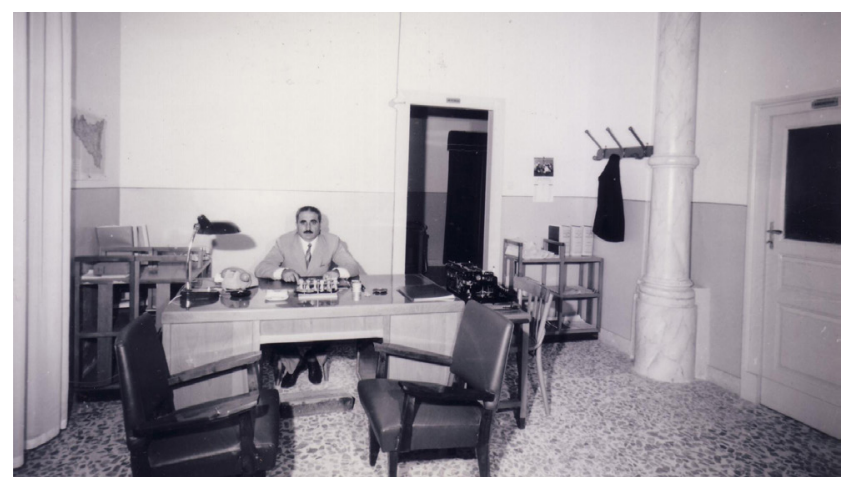

In the reconstruction of the Alessandria and Suburra districts of Rome [Cianci et al. 20I4; Cianci 20 I6, pp. 80-90], three levels of model authenticity were defined: complete reconstruction from archival elevations and historical photographs, partial reconstruction from archive plans and current elevations, and typological reconstruction from cadastral maps compared with the abacus of typologies.

A different solution was proposed for the virtual reconstructions of the Roman Forum, which were accompanied by a WIKI platform containing the sources and the reconstructive process for each single 3D model [Bartz et al. 2016].

A further "Reconstruction-Argumentation Method" [Pfarr-Harfst et al. 2016] associates screenshots and 3D model renderings with source tables and explanatory text in a "Reconstruction-Argument-Source" triad with qualitative evaluation of reliability.

Another possibility is the formal "Extended Matrix" [Demetrescu 20 I 5, pp. 42-55] language, which implements a stratigraphic approach to document the sources and corresponding interpretations underlying virtual reconstruction projects.

\section{The kitchens of the Benedictine Monastery in Catania}

The revered Monastery of San Nicolò l'Arena is an iconic site in the City of Catania. Construction began in 1558 on the Hill of Montevergine, and the monastery was first afflicted by the lava flow of 1669 and then by the earthquake of 1693. Starting from 1866, the monastic complex underwent numerous transformations to adapt the building for different civil designations.

In 1739, architect Giovan Battista Vaccarini commenced construction of the kitchen and basement areas, locally referred to as the 'ventre' (belly), directly on the lava flow of I669. The monastery subsequently became seat of the Royal Astrophysical Observatory between the end of the nineteenth and the first half of the twentieth century.

The University of Catania acquired the monastery in the 1970s and embarked on a long and laborious restoration process that led to the use of the building as the seat of the Department of Humanities and the establishment of the Museo della Fabbrica. 


\section{Methodology}

The methodology began with historical documentation (images, cartographies, and drawings) and archive (Museo della Fabbrica, Archivio di Stato) research, followed by metric surveying using direct techniques integrated with photogrammetry, a consolidation phase to identify the most significant transformations and prepare the framework for relevant paradata and reliability scales, and finally, a 3D modelling and rendering phase.

\section{Archival and historic research}

Documents, historical photographs, articles and other work concerning the history of the monastery and its restoration were sourced from the Archives of the Museo della Fabbrica. Original documents relating to the construction of the access staircase to the specola and accommodation for the staff of the Royal Observatory of Catania (fig. 3) were found at the State Archives of Catania [lozzia 2019-20 I0].These documents provide information on the demolished levels and reveal traces of the kitchens in their original configuration, including three ventilation domes in the main kitchen section, which are also seen in Léon Dufourny's sketches of I789 (fig. 4).

\section{Architectural surveying}

Direct surveying was implemented to verify and complement the technical office documentation of the University. Some photographic datasets were developed using Metashape (Agisoft) (fig. 5) to create textured polygonal models on which the necessary measurements would be based.

Fig. 3. Project for the construction of the acces staircase to the specola and accommodation for the staff of the Royal Observatory of Catania, longiaedicula, 1887

Fig. 4. Léon Dufourny Kitchen plan and crosssection, 1789
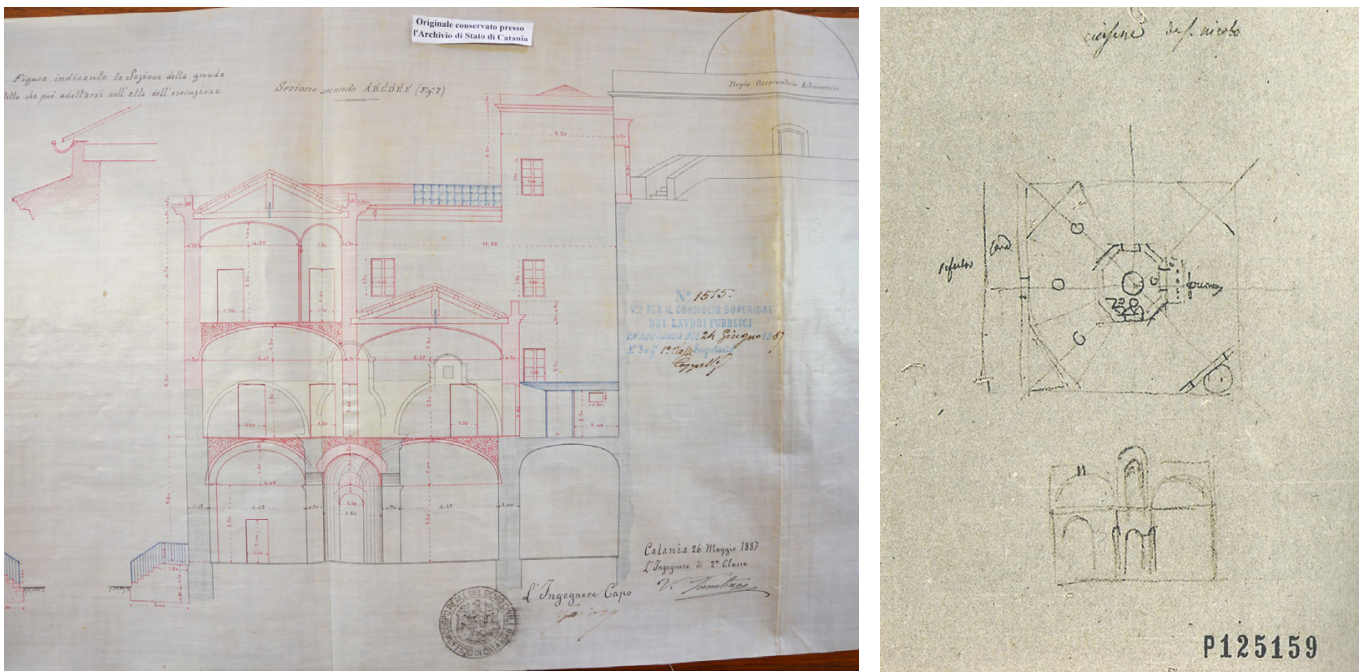

\section{Virtual reconstruction}

Three main transformation phases concerning the kitchens were, in reverse chronological order, its modern configuration, the Royal Astrophysical Observatory phase (I 887 - mid20th), and the Benedictine Monastery phase (1669-|867). 


\section{Current configuration (since mid-20th)}

The kitchen areas (fig. 6b) have a rectangular planimetric layout, with internal access from the Refectory (nowadays the main hall) through a passageway and external access (Piazza Vaccarini) via a connecting hallway. The entrance hall is closed by a stairwell (built during the Royal Observatory phase) that provides access to the upper levels.

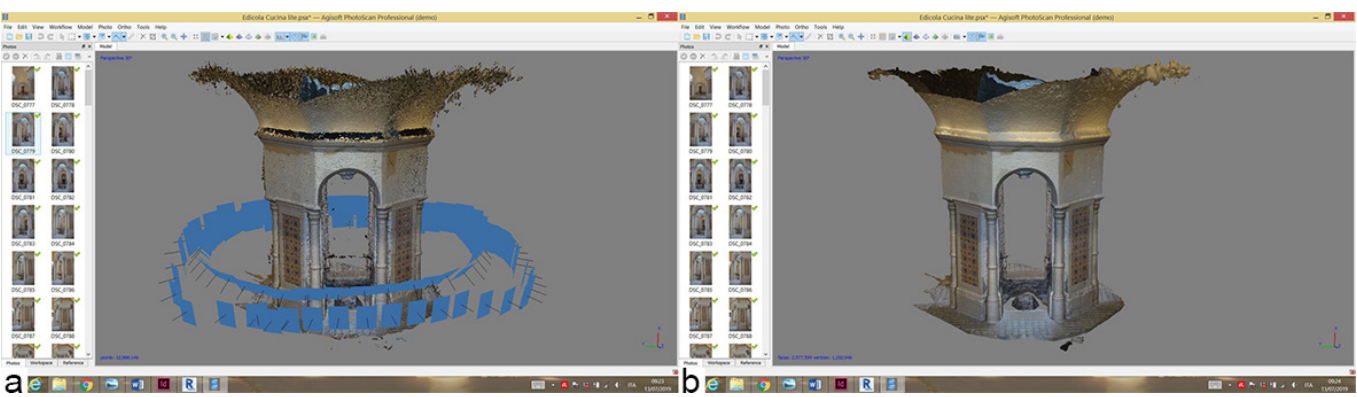

The kitchens consist of a quadrangular room with an aedicula, or oven, in the center on an octagonal base with four arched openings supported by columns oriented along the axes of the square. A cornice above the aedicula supports an annular vault ceiling on an octagonal base, with gracious half-sails providing the transition from the square to the octagonal geometries. The annular vault and the chimney are reproductions of the originals that were demolished at the end of the nineteenth century.

The original staircase leading to the basement and three circular holes for the passage of food is arranged along the diagonals of the room.

On the west side, the kitchens border with a construction built in 1927, which today houses the service rooms of the Museo della Fabbrica and a new stairway down to the lower level, flanked by an elevator.

The semi underground level occupies a large area below the kitchens, the small refectory, part of the library and the clock corridor. The so-called 'ventre' (belly) refers to the area beneath the kitchens (fig.6a); the area below the small refectory and the hallway was mostly occupied by the Geodynamics Laboratory, of which a large seismometer, and pieces of other tremor measuring equipment and a pendulum remain today.

The 'ventre' area is delimited by pillars and arches that lie directly on the lava bank and support cross vaults.
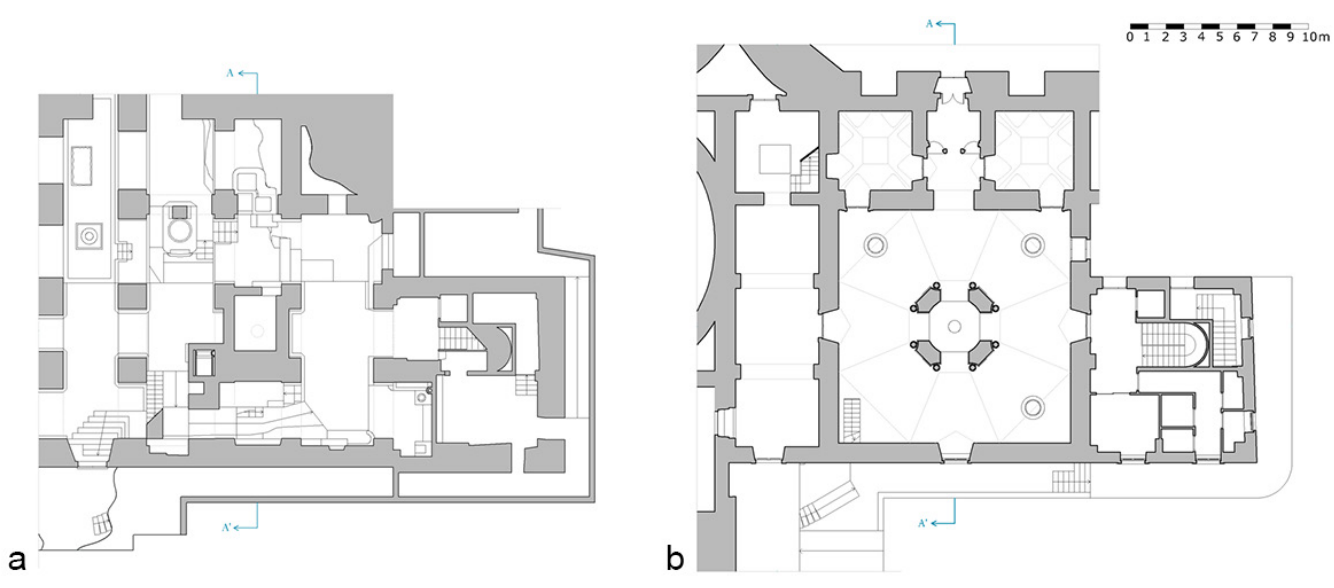
The semi underground environment is illuminated to the north by three windows overlooking the square and an entrance found during the restoration activities. The cross vault at this entrance retains traces of a staircase that once provided immediate access to the Geodynamics Laboratory from the entrance hall (fig. 7).

\section{Royal Astrophysical Observatory (I887 - mid-20th)}

One of the most significant interventions carried out by the Observatory was the construction of two levels above the kitchens and the hallway, which involved the elimination of the original kitchen vault along with the three small ventilation domes and the chimney.

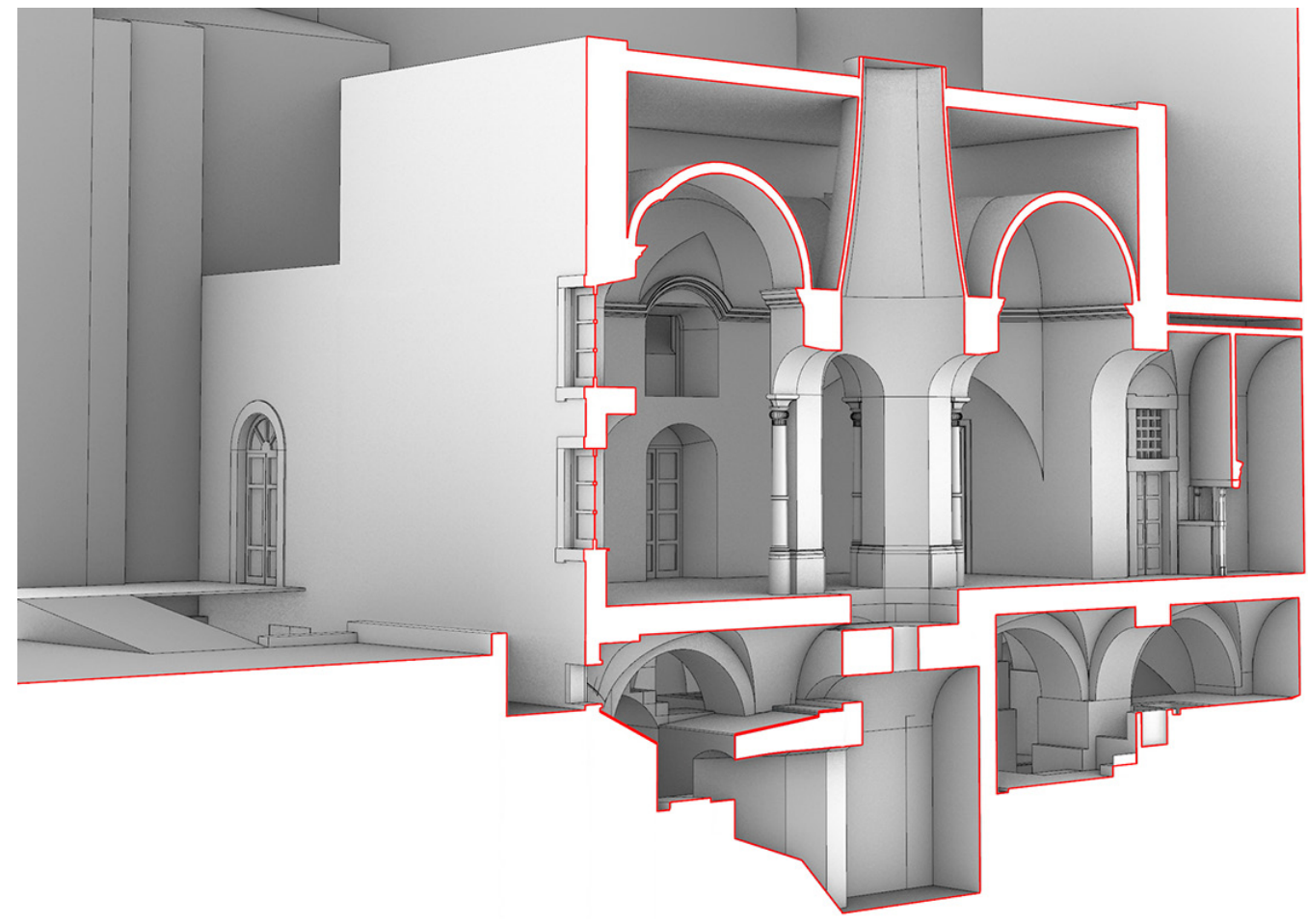

The 3D ground floor reconstruction (fig. 8b) was based on survey designs of the Technical Office in the 1970s and compared with the historical photos of the individual rooms. The 1887 project instead provided supporting material for modelling the upper levels (figs.8c, $8 \mathrm{~d}, 8 \mathrm{e}$ ). Only part of the semi underground environment (fig. 8a) was used for the Geodynamics Laboratory (area below the entrance hall and the small refectory), and it was partially modelled from in situ evidence, historical photos and a sketched plan of the rooms.

\section{Benedictine Monks (1669-1867)}

The restoration work returned some of the original aspects of the building, including the main room with the octagonal ring vault, the oven designed by Vaccarini and the transom windows.

Virtual reconstruction of the elements that were not restored or were actually further 
modified during restoration was based on Léon Dufourny's sketches of 1789 (fig. 4), on the report of the cession of the monastery drawn up by the engineer Carlo Bettoli on January 4, I 868 on behalf of the State Property and Taxes Management, on Vaccari's I 88 I survey and onthe 1887 project of the Royal Astrophysical Observatory (fig. 3).

From Dufourny's sketches and the report of engineer Bettoli [Rizzo Pavone et al. 2000, p. 56], we deduced that there were some stoves near the aedicula and four walls in the central room of the kitchen, closing the four corners. Dufourny had also represented three small domes placed above the ring vault of the kitchen.

Confirmation of these elements together with other useful information regarding the North and West elevations were provided by the Royal Astrophysical Observatory project (1887). For the roofs, the report of the cession indicates a vault in cane and gypsum in the west chamber with a pitched overhanging roof [Rizzo Pavone et al. 2000, p. 56]. In the absence of similar documentation for the central room and the entrance hall, we assumed more pitched roofing for the former and an open space for the latter (due to the presence of doors and transom windows).
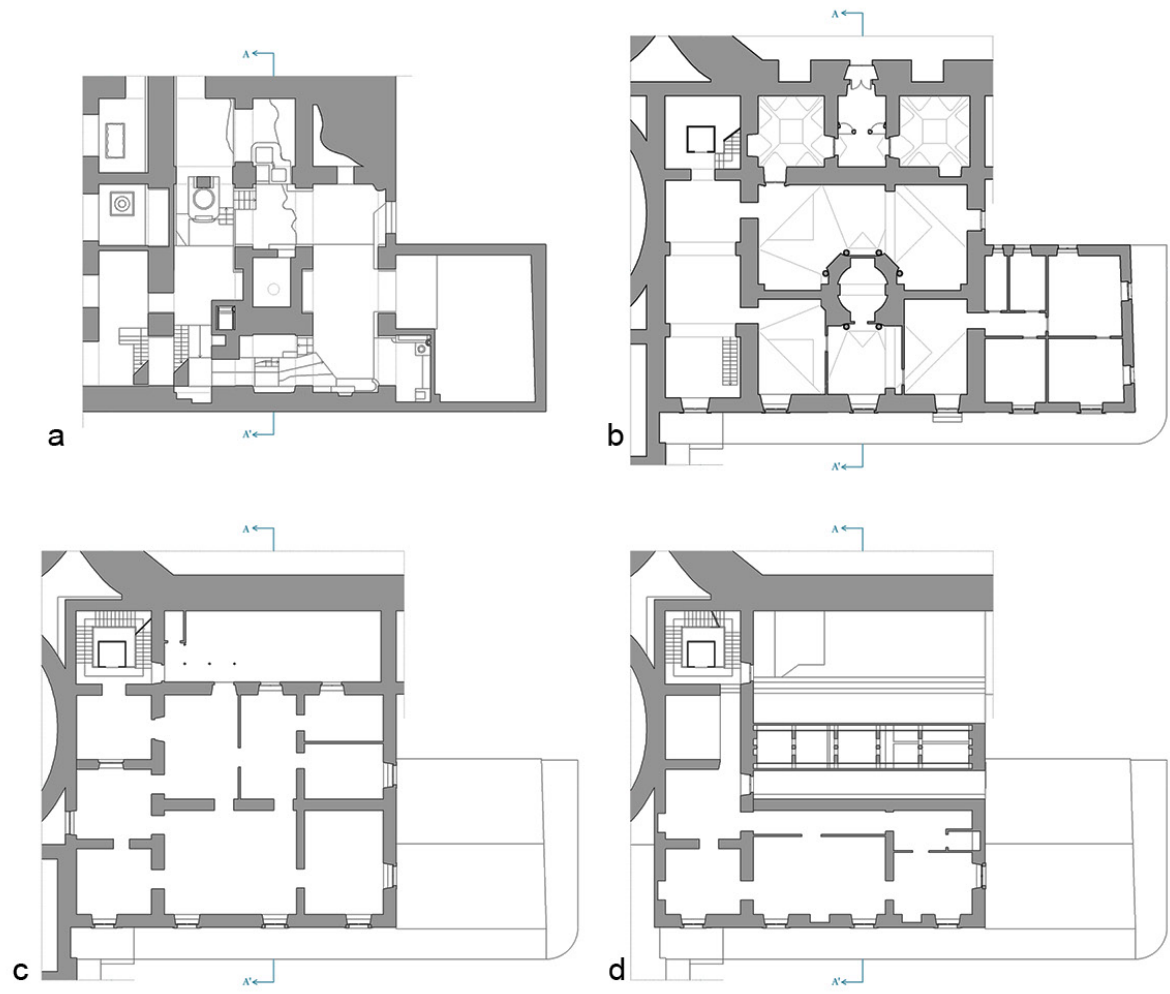

d

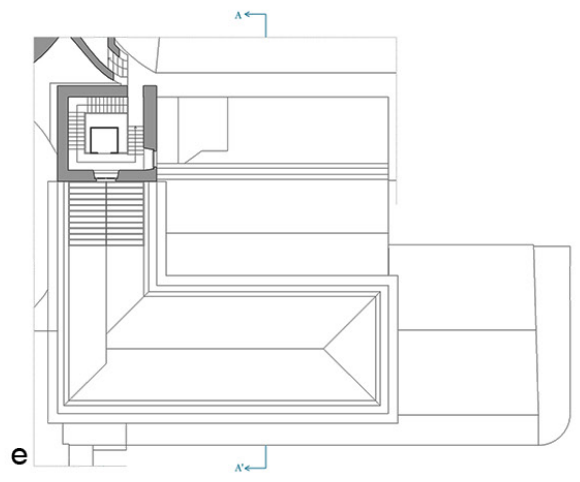


No graphic material was sourced for the 'belly', so it can only be assumed that the West side was originally limited to the room with the two ovens.

The restoration work revealed an ancient entrance from Piazza Vaccarini that had been closed during the years of the Geodynamics Laboratory and subsequently restored by the University. Even though no visible signs of a staircase associated with this opening were found, it is presumed that one would have been present during its first phase as a monastery. Finally, the interpretation of Vaccaro's | 88 I survey and the presence of what seems to be a window, suggest that even the Western front was not completely below the external elevation in the past.

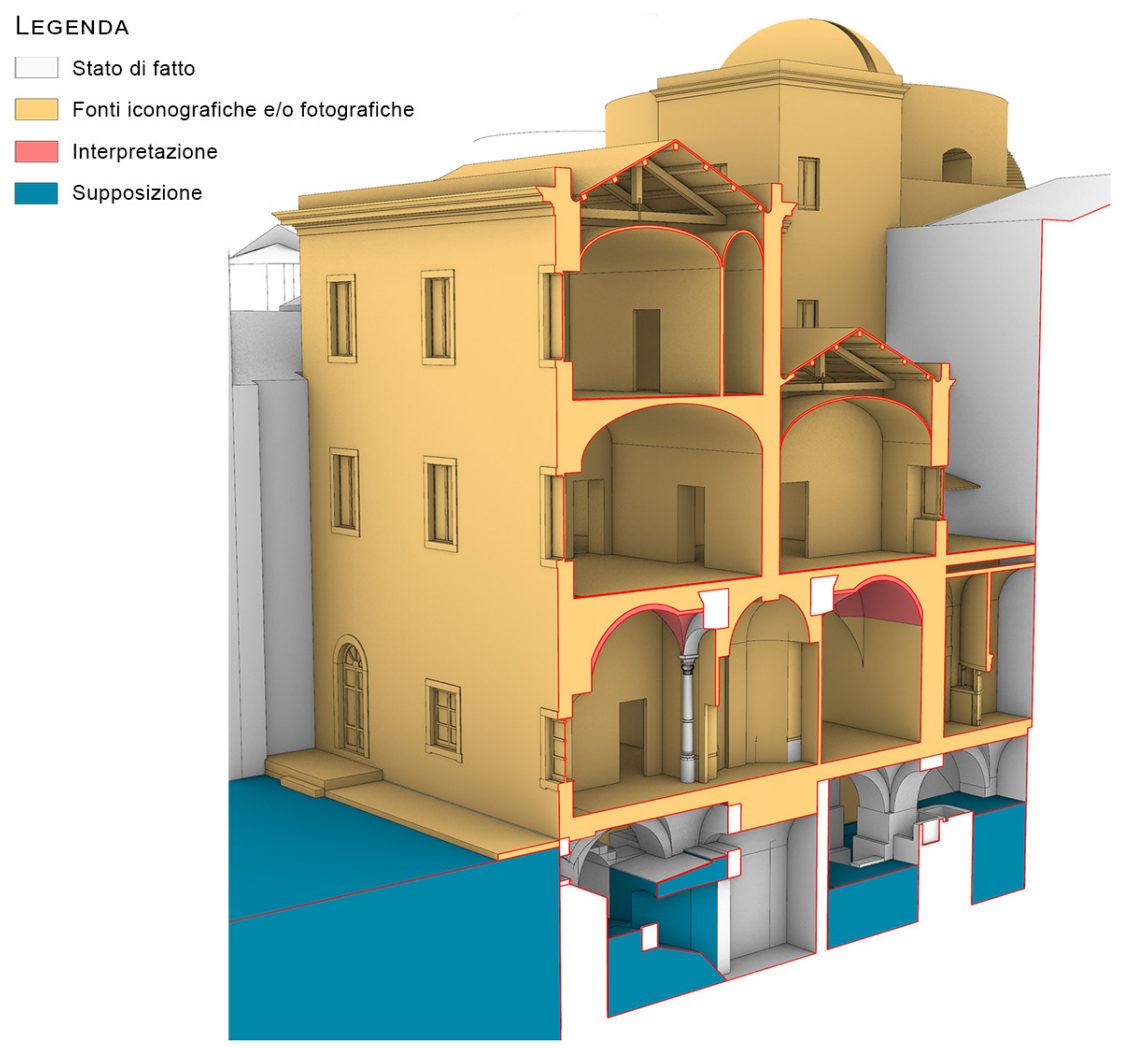

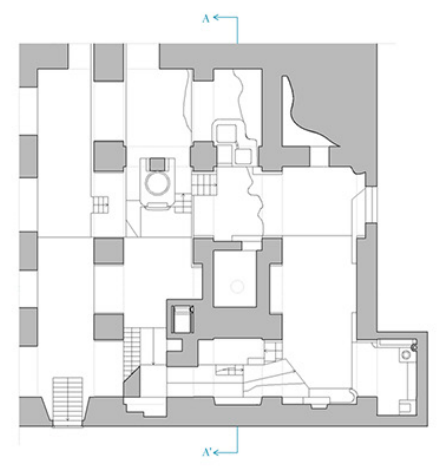

a

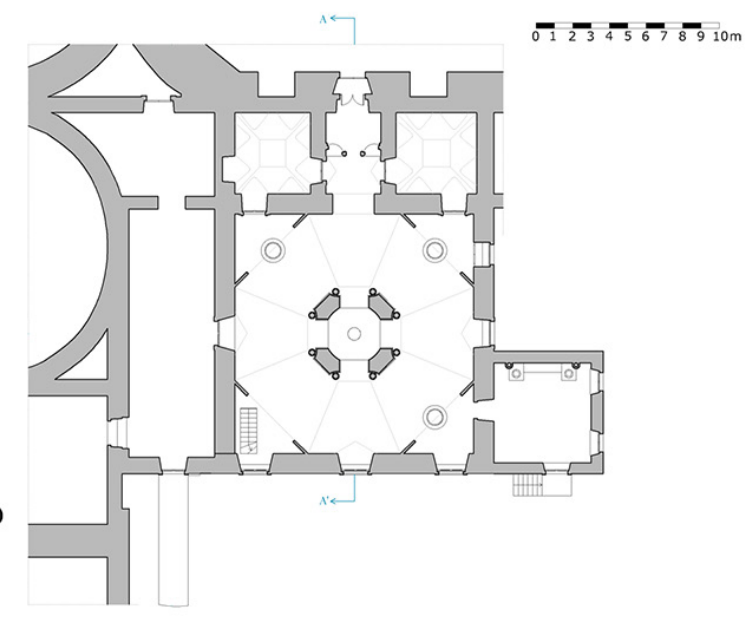




\section{Paradata visualization}

Two approaches were used to record the paradata and view the information as part of the virtual reconstruction.

The first method provides visual indication of the degree of reliability of each part of the model using different colors to represent one of the following categories: current manifestation, derived from iconographic sources and/or historical photos, interpretation, supposition. The second method uses the Rhinoceros environment to associate all relevant information concerning the individual components in the model (fig. I2). This information can be accessed inside the virtual environment in the Properties window, under the "attributes user text" tab. The same attributes can also be imported or exported in .cvs and .txt format.

Fig. II.Axonometric cross-section of the virtual reconstruction of the Benedictine Monks phase.

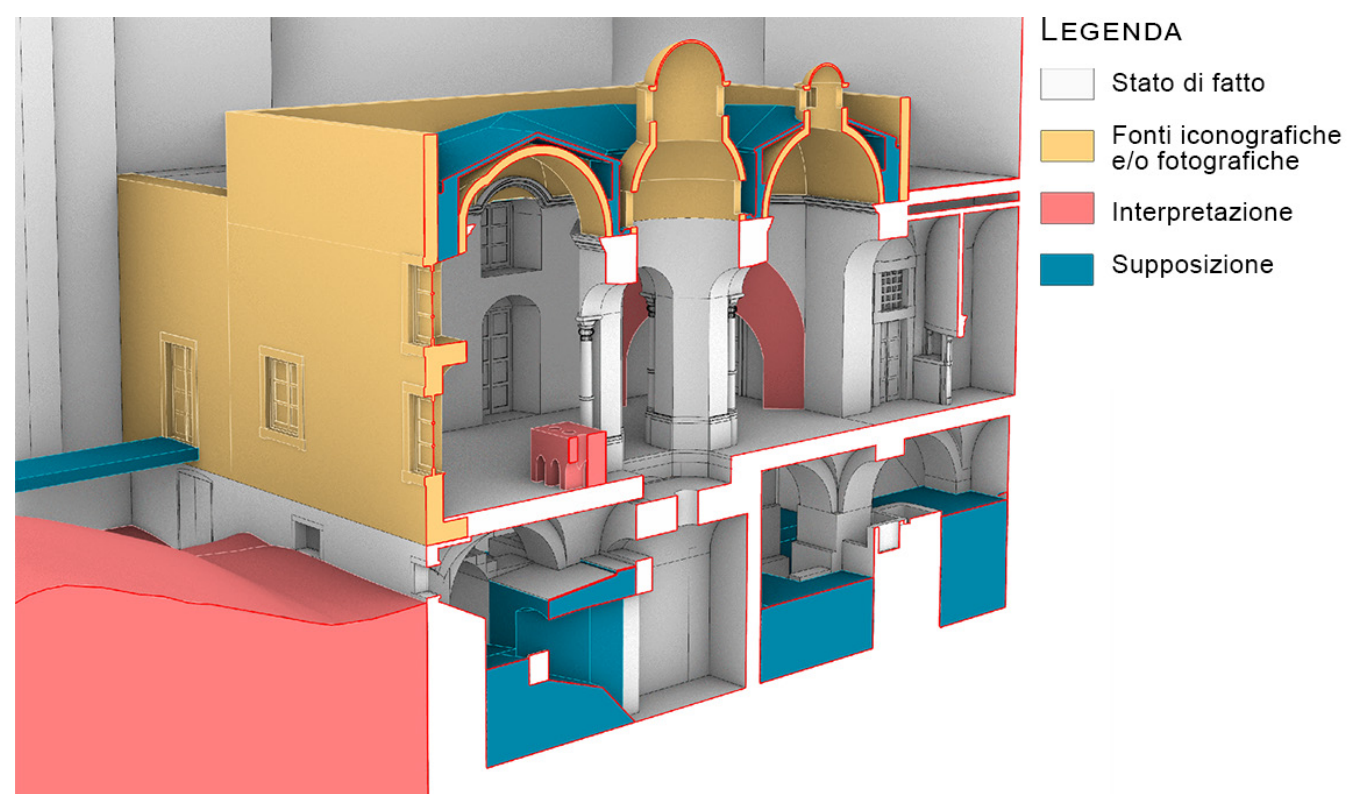

\section{Conclusions and future developments}

The aim of this research project is to reconnect present and past through digital representation. Virtual reconstruction is a profoundly effective instrument of visual communication, not only for its ability to excite senses and pique interest, but also for the depth and complexity of knowledge that it can deliver, especially with an accompanying narrative. It is therefore fundamental to associate appropriate paradata that traces the reconstructive process.

The 3D models created for the Monastery of the Benedictines facilitate the comparison between different eras and spatial configurations, and can be used together with other disciplines such as film or video games in order to achieve even greater immersion, and in the process help achieve the ultimate goal of fomenting a closer relationship with our cultural heritage.

\section{Credits}

Cettina Santagati wrote the paragraphs Introduction, State of the Art, Methodology, Conclusions and future developments. Nicoletta Campofiorito wrote the paragraphs: The kitchens of the Benedictine Monastery in Catania, Archival and historic research, Architectural Surveying, Virtual reconstruction. 
Fig. 12. Demonstrative screenshot for the proposed procedure of archiving and displaying paradata on Rhinoceros 6).

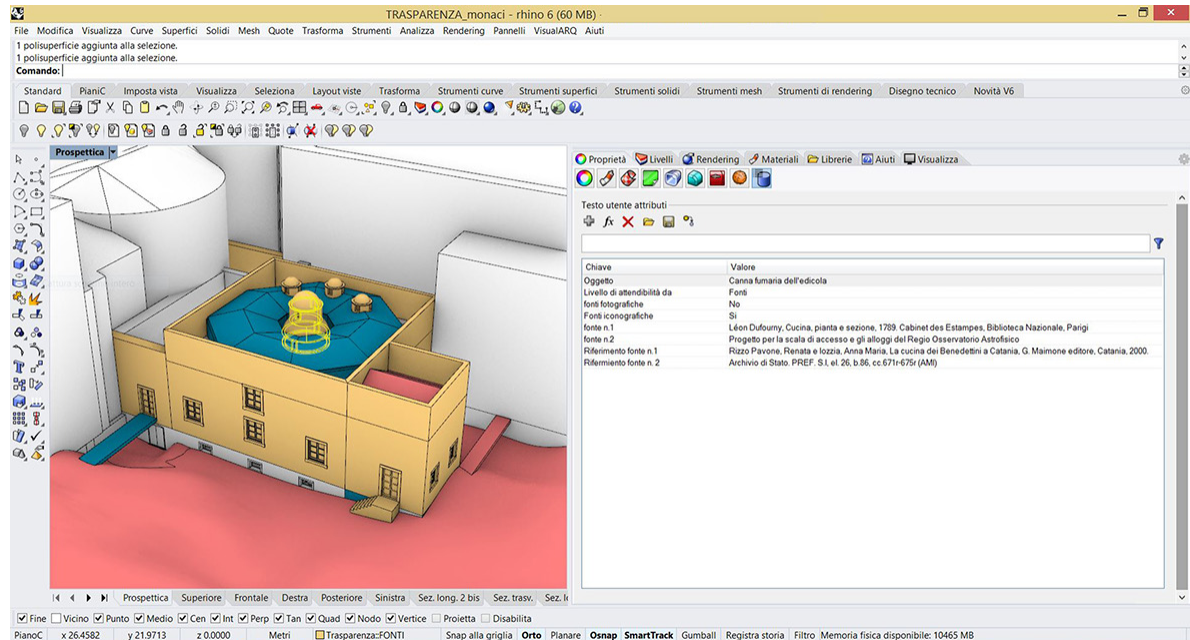

\section{References}

Bartz lessica, Holter Erika, Muth Susanne (2016). Digitales Forum Romanum. Chancen und Grenzen virtueller Rekonstruktion und Simulation. In Zimmer Kathrin Barbara. Von der Reproduktion zur Rekonstruktion - Umgang mit Antike(n). II Summerschool vom 16-19 Juni 2014 in Tübingen, vol. 21 , pp. 193-208. Rahden/Westf:Verlag Marie Leidorf GmbH.

Bentkowska-Kafel Anna, Denard Hugh, Baker Drew (a cura di) (2012). Paradata andTransparency in Virtual Heritage. Farnham: Ashgate.

Brusaporci Stefano (2017). The Importance of Being Honest: Issues of Transparency in Digital Visualization of Architectural Heritage. In Ippolito Alfonso (ed.). Handbook of Research on Emerging Technologies for Architectural and Archaeological Heritage. Hershey: IGI Global Gl Global, pp. 66-93.

Brusaporci Stefano, Trizio Ilaria (2013). La Carta di Londra e il Patrimonio Architettonico: riflessioni circa una possibile implementazione. In SCIRES-IT. SCientific RESearch and Information Technology, 3, Issue 2, pp. 55-68.

Cianci Maria Grazia, Calisi Daniele, Geremia Francesca (2016). II quartiere Alessandrino. Una ricostruzione virtuale filologica ed emblematica: alla ricerca dei valori originali dei tessuti urbani demoliti. In AAVV. Atti del Convegno Internazionale on Cultural Heritage. Present Challenges and Future Perspectives. Roma, 2 I-22 novembre 2014. Roma: Croma.

Cianci Maria Grazia (2016). Gestione, ricostruzione e comunicazione di sistemi urbani complessi. II quartiere della Suburra a Roma. In Disegnare Idee Immagini, 52, pp. 80-90.

Demetrescu Emanuel (2015). Archaeological stratigraphy as a formal language for virtual reconstruction. Theory and practice. In Journal of Archaeological Science, 57, pp. 42-55.

lozzia Anna Maria (a cura di). (2009-20 I0). Percorsi di storia e traguardi scientifici dell'Osservatorio Astrofisico di Catania. Mostra allestita presso l'Archivio di Stato di Catania dal 16 dicembre 2009 al 27 febbraio 2010.

Pfarr-Harfst Mieke, Grellert Marc (2016). The Reconstruction - Argumentation Method. Proposal for Minimum Standard of Documentation in the Context of Virtual Reconstructions. In loannides Marinos et al. (Eds.). Digital Heritage. Progress in Cultural Heritage: Documentation, Preservation, and Protection. EuroMed 20 16. Lecture Notes in Computer Science. Cham: Springer, vol. 10058, pp. 39-49

Rizzo Pavone Renata, lozzia Anna Maria (2000). La cucina dei Benedettini a Catania. Catania: G. Maimone editore.

Yourcenar Marguerite (2005). Memorie di Adriano. Seguite dai taccuini di appunti.Torino: EinaudiTraduzione di Storoni Mazzolani, Lidia (Ed. orig. Mémoires d'Hadrien. Paris: Librairie Plon, 1951).

\section{Website}

<http://osiris.itabc.cnrit/extendedmatrix/>

$<$ http://www.digitales-forum-romanum.de/>

\section{Authors}

Nicoletta Campofiorito, Università degli Studi di Catania, nicoletta.campofiorito@gmail.com Cettina Santagati, Università degli Studi di Catania, cettina.santagati@unict.it

To cite this chapter. Campofiorito Nicoletta, Santagati Cettina (2020). Riconnettere presente e passato: la ricostruzione virtuale delle cucine de Monastero dei Benedettini a Catania/Reconnecting present and past: the virtual reconstruction of the kitchens of the Benedictine Monastery in Catania. In Arena A., Arena M., Brandolino R.G., Colistra D., Ginex G., Mediati D., Nucifora S., Raffa P. (a cura di). Connettere. Un disegno per annodare e tessere. Atti del $42^{\circ}$ Convegno Internazionale dei Docenti delle Discipline della Rappresentazione/Connecting. Drawing for weaving relationships. Proceedings of the 42th International Conference of Representation Disciplines Teachers. Milano: FrancoAngeli, pp. I800-1819. 